\title{
A comparative study of nutrient transfer via surface runoff from two small agricultural catchments in north China
}

\author{
Haiming Lu · Chengqing Yin · Weidong Wang · \\ Baoqing Shan
}

Received: 14 September 2006/ Accepted: 26 November 2006/Published online: 19 December 2006

(C) Springer-Verlag 2006

\begin{abstract}
A field study was conducted to determine the effect of landscape spatial pattern and microtopography on nutrient transfer via runoff from two catchments into Yuqiao Reservoir in north China. The surface runoff discharge was measured during rainfall events and water samples were analyzed in 2004 and 2005. The mean annual total nitrogen (TN) and total phosphorus (TP) exports per unit area from Caogezhuang catchment ( $\mathrm{C}$ catchment) were 1.048 and $0.561 \mathrm{~kg} \mathrm{ha}^{-1}$ year $^{-1}$, respectively, while the TN and TP exports from Taohuasi catchment ( $\mathrm{T}$ catchment) were 0.158 and $0.027 \mathrm{~kg} \mathrm{ha}^{-1}$ year $^{-1}$. In both catchments, village and vineyard shared the highest nutrient export ability due to the accumulated animal waste and heavy application of fertilizer and manure. In $\mathrm{T}$ catchment, the distance of village and vineyard was about $1,500 \mathrm{~m}$ away from the receiving water and in between were woodland and cropland. In the hydrological pathway, there were sink landscape structures of small stone dams, roadside swale, vegetated filter strip and dry ponds, which could detain water and nutrients. In $\mathrm{C}$ catchment, the distance between the village and the receiving water was about $200 \mathrm{~m}$, and the hydrological pathway was compacted roads and ditches with no sink structures. It is suggested that the distance between the pollution source area and the receiving water and the micro-topographical features were the main factors to control the great difference in nutrient export rates.
\end{abstract}

H. Lu · C. Yin $(\varangle) \cdot$ W. Wang $\cdot$ B. Shan

Research Center for Eco-Environmental Sciences,

Chinese Academy of Sciences, Shuangqing Road 18,

Beijing 100085, People's Republic of China

e-mail: cqyin@263.net
Keywords Agricultural catchment . Landscape spatial pattern · Micro-topography . Nutrient transfer - Surface runoff

\section{Introduction}

The degradation of soil and water quality by excessive nutrient input from agriculture has become an international environmental issue. The agricultural contribution to diffuse pollution varies widely and is a complex function of soil type, climate, topography, and hydrology, land use and land management $(\mathrm{Li}$ and Zhang 1999; Smith et al. 1999; McDowell et al. 2001; Withers and Lord 2002; Heathwaite et al. 2003). Human activity has changed nutrient balance and hydrological processes, and water quality has deteriorated in many human-dominant landscapes (Smith et al. 1999; Boyer et al. 2002; Withers and Lord 2002; Cao 2003; Liu and Xia 2004). Excessive input of fertilizer and manure in cultivated soil has been proven to be an important cause of surface water deterioration (Li and Zhang 1999; Herpe and Troch 2000; Cao 2003; Ngoye and Machiwa 2004; Cao et al. 2006). Besides the agricultural land, wastewater and garbage produced by residents of rural areas have also been identified as an important source of pollutants in surface waters in China (Cao 2003; Xia et al. 2003; Chen et al. 2004; Cao et al. 2006).

As some surface water is used for drinking water, the deterioration of water quality poses a threat to the drinking water supply. The Yuqiao Reservoir was constructed in 1970s for drinking water supply and help prevent floods. The reservoir supplies most of the drinking water for Tianjin, the third largest city in 
China. A large population and intensively fertilized cultivated land are in the zone adjacent to the reservoir. Recently, the reservoir has been in a state of eutrophication. Nutrients from agricultural catchments have been identified as the primary contributor (Zhu 1991; Chen et al. 2005).

Surface runoff caused by rainfall is one of the primary transport pathways for nutrient transfer from the original site to the receiving water (McDowell et al. 2004; Haygarth et al. 2005; Heathwaite et al. 2005). Nutrients are derived in the dissolved form and particulate form through solubilization and detachment mechanisms from natural and human sources, and then delivered into surface water via various hydrological pathways. In general, semi-arid areas are dominated by the Horton overland flow, which occurs as a result of prolonged rainfall at intensities greater than the infiltration capacity of the soil (Bergkamp 1998; Cammeraat 2004). Runoff events occur very quickly after the onset of rainfall, but also cease directly after rainfall has stopped.

The potential contribution areas for surface runoff generation and nutrient export vary spatially and temporally in those regions where the dominant runoff generation mechanisms are either saturation-excess or infiltration-excess. Areas with high nutrient export are often identified as "hydrologically sensitive areas" (HSAs) and "critical source areas" (CSAs) (Walter et al. 2000; Weld et al. 2000; Heathwaite et al. 2003). In a catchment with high spatial heterogeneity, various landscapes and patches can be categorized as "source" or "sink" landscapes and patches according to their roles of transportation or detention. The number and spatial patterns of source and sink landscapes and patches within a catchment can affect hydrological and nutrient transport processes at different scales (Mander et al. 2000; Chen et al. 2002; Kirkby et al. 2002; Imeson and Prinsen 2004; Ngoye and Machiwa 2004; Chen et al. 2005).

Micro-topography has been proven to be a dominant control of water flow. A number of previous studies conducted in the Mediterranean with a semiarid climate showed that micro-topography could exert a great impact on surface runoff generation, soil erosion, and vegetation pattern at the finer scale (Bergkamp 1998; Kirkby et al. 2002; Cammeraat 2004; Imeson and Prinsen 2004). Bergkamp (1998) measured runoff and infiltration to understand the relationship between runoff production, vegetation pattern and microtopography at five spatial scales from terracette $(<1 \mathrm{~m})$ to catchment (50 ha). He found that runoff did not occur at the slope scale. It was buffered at the terracette level by non-uniform infiltration at the rims of terracettes and at the hummock scale by rapid infiltration under oak shrubs and trees. Models, such as Topmodel, TopManage et al., have been used to simulate the effect of topography on runoff generation and nutrient transfer (Beven and Kirkby 1979; Lane et al. 2004; Heathwaite et al. 2005).

In this paper, two agricultural catchments adjacent to the Yuqiao Reservoir were selected to investigate the effects of landscape spatial patterns and microtopography on nutrient transfer. Goals were: (1) to compare the human role in nutrient transfer from the two catchments; (2) to investigate the effect of spatial patterns of landscapes and patches on nutrient export; (3) to present some suggestions for the reduction of nutrient export.

\section{Materials and methods}

\section{Site description}

The Yuqiao Reservoir is northeast of Tianjin, and has a mean water depth of $4.6 \mathrm{~m}$, surface area of $86.8 \mathrm{~km}^{2}$ and a full water capacity of $15.6 \times 10^{9} \mathrm{~m}^{3}$ (Fig. 1a). A population of about 116,000 people and $70 \mathrm{~km}^{2}$ of cultivated land is adjacent to the Yuqiao Reservoir. The hill slope on the southern bank is steeper and shorter than the slope on the northern bank. The climate is temperate, territorial semi-arid with warm summers and cold winters. The mean annual temperature is $11.5^{\circ} \mathrm{C}$. The annual evaporation ranges from 1,660 to $1,954 \mathrm{~mm}$, with a mean annual precipitation of $601 \mathrm{~mm}$.

Two agricultural catchments, Taohuasi (abbreviated as $\mathrm{T}$ catchment) on the northern bank and Caogezhuang (abbreviated as C catchment) on the south bank, were selected for study (Fig. 1a). The northern part of $\mathrm{T}$ catchment consists of rolling hills. Many deep gullies, depressions and channels exist in the ridges and hills. C catchment is a continuous steep slope. Soil textures in $\mathrm{T}$ catchment are sandy soil, sandy loam, and sandy clay respectively from hill land to cropland. In $\mathrm{C}$ catchment are sandy soil and sandy clay from hill land to village.

The landscape spatial distribution in the study catchments is mapped in Fig. 1b. The areas of main land uses in C catchment are hill land, 7.1 ha, cropland and orchard, $37.7 \mathrm{ha}$, and village, $8.1 \mathrm{ha}$. The areas of various land uses in $\mathrm{T}$ catchment are as follows: hill land, 111.5 ha; cropland and orchard, 61.6 ha; village, $5.5 \mathrm{ha}$; vineyard, $2.1 \mathrm{ha}$; and woodland, 7.1 ha. Hill land accounts for about $60 \%$ of the whole catchment area. Most of the hill land did not contribute any surface water to lowlands during the study period due to 
(a)

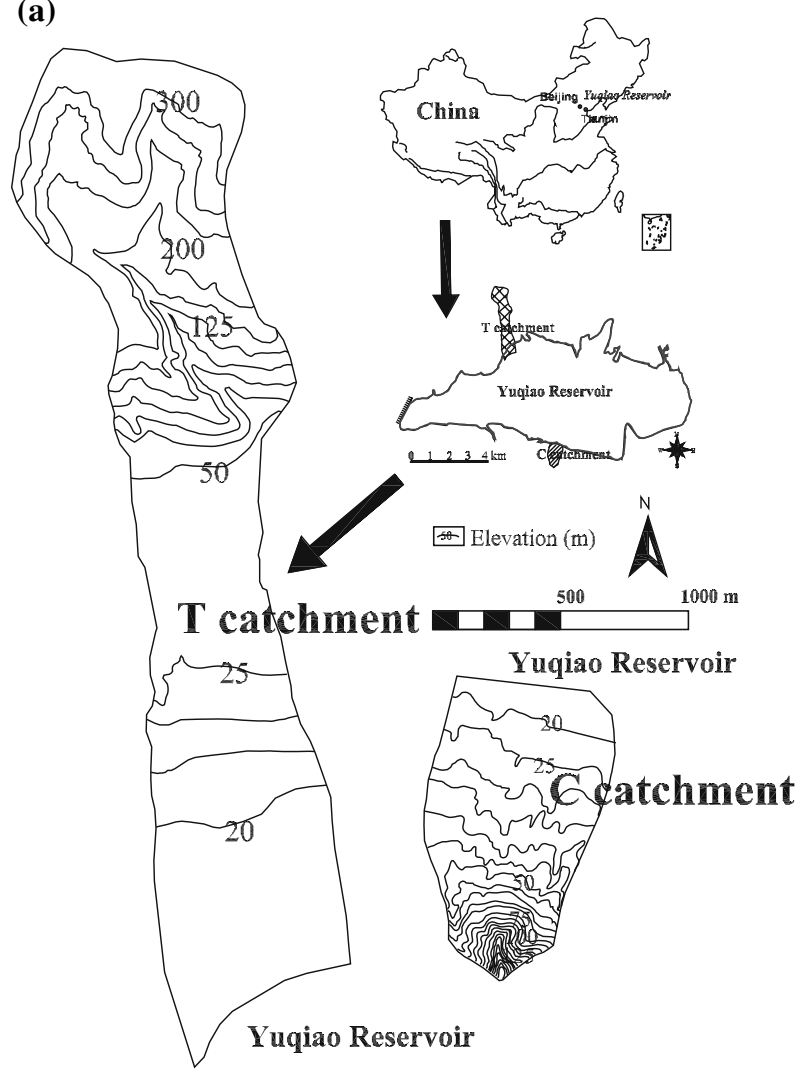

(b)

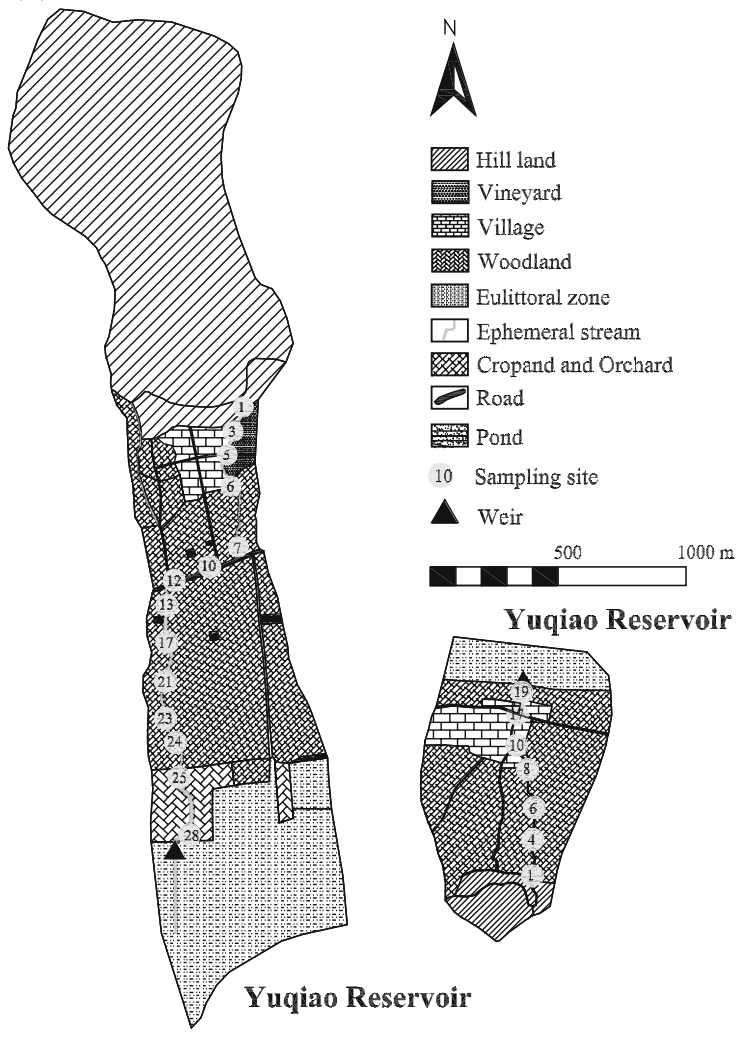

Fig. 1 Location of the study area, catchment terrain (a) and landscape spatial distribution in the study catchments (b) the large storage capacity of deep gully and depressions, which function as small, temporary impoundments. Only surface water from hill land directly facing the village and orchard flows into the lowland. Areas contributing little surface water received little human use and these hilly areas can be excluded when considering human influence on nutrient emissions. Certain low-lying areas below the woodlands in $\mathrm{T}$ catchment and below the village in $\mathrm{C}$ catchment are submerged when the water level is high in the Yuqiao Reservoir. Otherwise, ground cover is sparse when the water level is low during the growing season. These periodically submerged wetland areas adjacent to forest are called eulittoral zones Wetzel (2001), or riparian zones (Wang et al. 2004, 2005).

The two catchments had almost the same number of residents, as well as livestock (Table 1). The fertilizer and manure application rate in cropland and orchards was about $300 \mathrm{~kg} \mathrm{~N} \mathrm{ha}^{-1}$ and $100 \mathrm{~kg} \mathrm{P}_{2} \mathrm{O}_{5} \mathrm{ha}^{-1}$, and that in vineyards was around $500 \mathrm{~kg} \mathrm{~N} \mathrm{ha}^{-1}$ and $250 \mathrm{~kg} \mathrm{P}_{2} \mathrm{O}_{5} \mathrm{ha}^{-1}$. The timing of fertilizer application was concomitant with the rainy season when crops grow fast at the optimal temperature. In $\mathrm{T}$ catchment, an ephemeral stream transports water and nutrients to the receiving waters during rainstorms, usually for no more than $24 \mathrm{~h}$ after rainfall. In $\mathrm{C}$ catchment, surface pathways for the transfer of water and nutrients are roads, lanes and field tracks with low infiltration rates, where the soil is compacted by farmers and machines.

Sample collection and analysis

The discharge of runoff was continuously measured through a $120^{\circ} \mathrm{V}$-notch concrete flume and an H-notch concrete flume (Fig. 1). A kinemometer was used to measure water velocity unless water levels were too low, Then the velocity of small plastic buoys was measured as distance (about $1 \mathrm{~m}$ ) over time. Water samples were collected manually for chemical analysis at the outlet at intervals of about 2-10 min dependent on the duration of runoff flow. Water samples of surface runoff in various land uses were also collected during rainfall-runoff events from 2004 to 2005.

To investigate nutrient spatial transport processes, a series of sampling sites was installed from upstream to the outlet in the two catchments. In $\mathrm{T}$ catchment, sampling sites included 28 sites to monitor surface flow in the stream channel and five for tributary flow from areas of different land uses. In C catchment, there were 19 sampling sites along an unpaved road, which acted as the main transport path. Surface water samples were taken manually. The time of sampling was recorded on the hydrograph. 
Table 1 Comparison of some basic conditions between the two catchments

\begin{tabular}{lll}
\hline & $\begin{array}{l}\text { Taohuasi catchment } \\
\text { (T catchment) }\end{array}$ & $\begin{array}{l}\text { Caogezhuang catchment } \\
\text { (C catchment) }\end{array}$ \\
\hline Drainage area & 192.1 ha & 54.2 ha \\
Potential anthropologic nutrient emission area & 86.6 ha & 54.2 ha \\
Population & 290 & 300 \\
Livestock & 1,000 laying hens; 20 cows; 100 goats; & 800 laying hens; 20 cows; \\
& $\quad 80$ pigs and 50 deer & 120 goats and 70 pigs \\
Landscape spatial pattern & Hill-village, vineyard, & Hill-cropland, \\
& orchard-village-eulittoral zone \\
Micro-topographical features in landscape & Terrace, field ridge, pond & Terrace, field ridge \\
Sink structures in transport pathway & Stone dams, grass filter strips, dry ponds & None \\
\hline
\end{tabular}

Immediately after collection, water samples were put on ice, stored at $4^{\circ} \mathrm{C}$, and analysed at the State Key Laboratory of Environmental Aquatic Chemistry within $48 \mathrm{~h}$ after sampling. Total nitrogen (TN) and total phosphorus (TP) were determined by peroxodisulfate oxidation (Ebina et al. 1983).

Load calculation was estimated from the instantaneous chemical and discharge data according to the following equation:

$l_{k}(j)=\sum_{i=1}^{k} \Delta t_{i}\left[c_{i}(j) Q_{i}+c_{i+1}(j) Q_{i+1}\right] / 2$

where $l_{k}(j)$ is the cumulative load of the $j$ th constituent at the $k$ th time interval from the catchment, $\Delta t_{i}$, the $i$ th sampling interval, $c_{i}(j)$, the instantaneous concentration of the $j$ th chemical and $Q_{i}$, the instantaneous stream discharge.

Daily precipitation data were obtained at a meteorological station of the Yuqiao Reservoir less than $10 \mathrm{~km}$ away. Data on fertilizer and manure application in the cultivated land were obtained from regular visits and questionnaires given to farmers.

\section{Results}

Rainfall and water output characteristics

The monthly and daily rainfall in the study period is shown in Figs. 2 and 3. Rain falls mainly from June to August, when vegetation grows rapidly and temperatures are high. Water output for different rainfall types is shown in Table 2. The distribution of water output of different types of rainfall in $\mathrm{C}$ catchment had less variation than $\mathrm{T}$ catchment. There was no water export for rainfall less than $20 \mathrm{~mm}$ in $\mathrm{T}$ catchment or less than $10 \mathrm{~mm}$ in $\mathrm{C}$ catchment, which can be considered as runoff generation thresholds. The mean annual runoff coefficients (defined as the ratio between water output from the whole drainage catchment and total rainfall within the year) of $\mathrm{T}$ and $\mathrm{C}$ catchments were 0.0016 and 0.0132 , respectively.

Nutrient export distribution among different rainfall types

Daily nutrient export from two catchments during the two-year study period is shown in Fig. 3. The distribution of TN and TP load among various rainfall types is similar to that of water volume (Table 2). There was no nutrient export in rainfall events $<20 \mathrm{~mm}$ in $\mathrm{T}$ catchment, or for events with $<10 \mathrm{~mm}$ in $\mathrm{C}$ catchment. Nutrient export in $\mathrm{T}$ catchment was more concentrated in fewer rainstorms than that in $\mathrm{C}$ catchment. Around a quarter of the nutrients exported from $\mathrm{C}$ catchment and $4 \%$ of the nutrients exported from $\mathrm{T}$ catchment occurred during 10 rainfall events with $20-30 \mathrm{~mm}$. Rainfall-runoff events with lower precipitation at higher frequency played a greater role in nutrient transfer for $\mathrm{C}$ catchment than for $\mathrm{T}$ catchment.

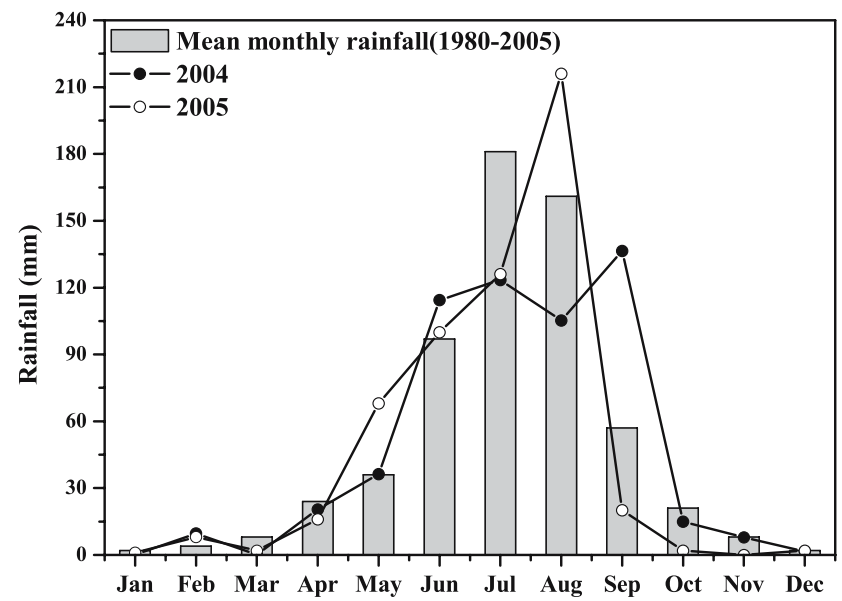

Fig. 2 Comparison of monthly rainfall in the years of 2004 and 2005 and mean monthly rainfall during 1980-2005 
Fig. 3 Daily rainfall, water and nutrient export from the two catchments during the rainy seasons (May-

September) of the two-year motoring period. Rainfalls less than $10 \mathrm{~mm}$ were not shown

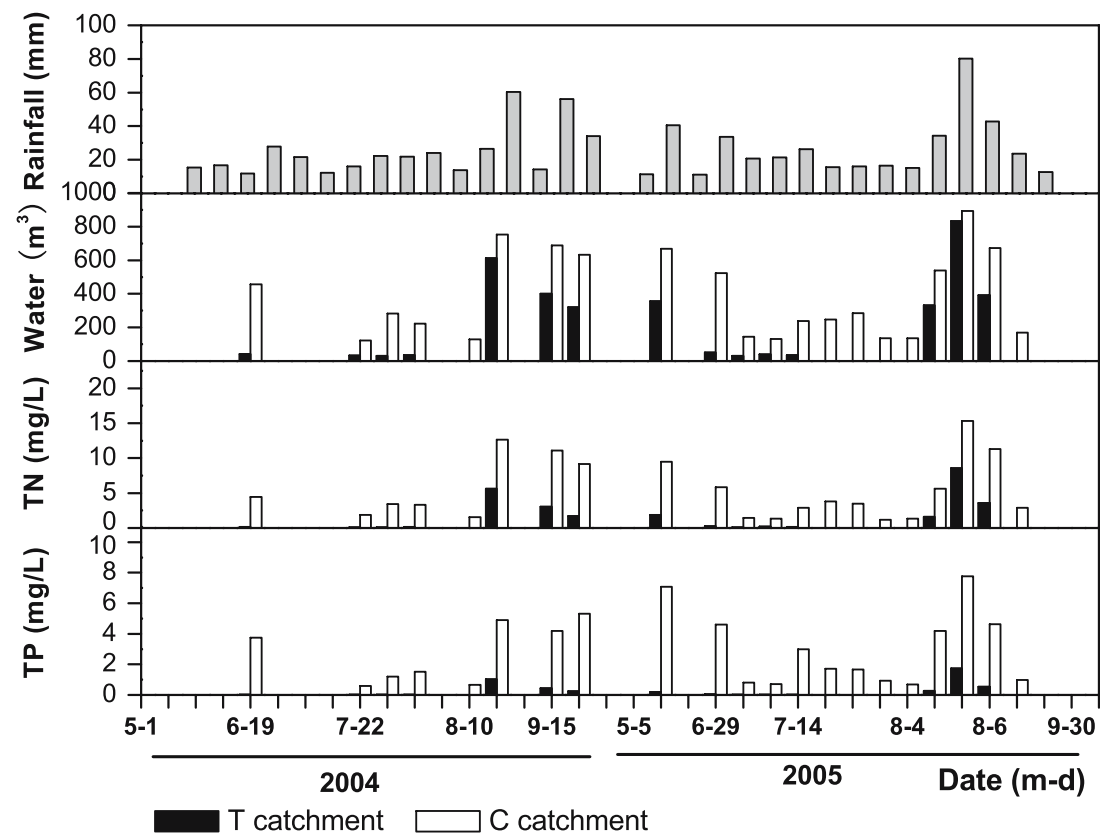

Table 2 Summary of water volume, TN load and TP load for different rainfall types

\begin{tabular}{|c|c|c|c|c|c|c|c|c|}
\hline \multirow[t]{2}{*}{ Rainfall type (mm) } & \multirow[t]{2}{*}{ Rainfall event } & \multirow[t]{2}{*}{ Rainfall (mm) } & \multicolumn{2}{|c|}{ Water volume $\left(\mathrm{m}^{3}\right)$} & \multicolumn{2}{|c|}{ TN load (kg) } & \multicolumn{2}{|c|}{ TP load (kg) } \\
\hline & & & $\mathrm{T}$ & $\mathrm{C}$ & $\mathrm{T}$ & $\mathrm{C}$ & $\mathrm{T}$ & $\mathrm{C}$ \\
\hline $0-10$ & 99 & $302(27)$ & $\S$ & $\S$ & $\S$ & $\S$ & $\S$ & $\S$ \\
\hline $10-20$ & 15 & 211 (19) & $\S$ & $804(10)$ & $\S$ & $9.9(8)$ & $\S$ & $5.0(8)$ \\
\hline $20-30$ & 10 & $236(21)$ & $250(7)$ & $1898(24)$ & $1.0(4)$ & $23.2(28)$ & $0.2(4)$ & $13.2(22)$ \\
\hline $30-40$ & 3 & $102(9)$ & $702(20)$ & $1693(21)$ & $3.6(13)$ & 20.7 (11) & $0.6(12)$ & $14.1(23)$ \\
\hline $40-50$ & 2 & $83(7)$ & $748(21)$ & $1340(17)$ & $5.5(20)$ & $20.8(28)$ & $0.7(15)$ & $11.7(19)$ \\
\hline $50-60$ & 1 & $56(5)$ & 402 (11) & $689(9)$ & 3.1 (11) & $11.1(11)$ & $0.5(10)$ & $4.2(7)$ \\
\hline$>60$ & 2 & 141 (12) & 1447 (41) & $1645(20)$ & $14.2(52)$ & 28.0 (14) & $2.8(59)$ & $12.7(21)$ \\
\hline Total & 132 & $1131(100)$ & $3550(100)$ & 8069 (100) & $27.3(100)$ & $113.6(100)$ & $4.7(100)$ & $60.8(100)$ \\
\hline
\end{tabular}

The number in parentheses is the percentage

$T$ Taohuasi catchment; $C$ Caogezhuang catchment, $\S$ no water and nutrient export

The annual export rates per unit area were also calculated based on nutrient export of 33 rainfall-runoff events. Mean TN and TP export rates in T catchment were 0.158 and $0.027 \mathrm{~kg} \mathrm{ha}^{-1}$ year $^{-1}$ on the basic of the anthropological emission area (86.6 ha). Comparably, mean TN and TP export rates in $\mathrm{C}$ catchment were 1.048 and $0.561 \mathrm{~kg} \mathrm{ha}^{-1}$ year $^{-1}$, about 6.6 times and 20.6 times higher than those in $\mathrm{T}$ catchment.

\section{Nutrient mobile potential of various landscapes}

Land covers, saturated soil hydraulic conductivity $(K d)$, and nutrient concentrations in the two catchments are presented in Table 3. In general, villages and vineyards showed the highest runoff generation ability and nutrient concentration. Hill land and woodland showed the lowest. Cropland and orchard ranged in the middle. Village and vineyard may be considered the "critical source area" in the two catchments.

The land cover in the village was mainly made up of impervious surfaces (houses, paved roads) and compacted earth surfaces (unpaved roads, yards) with low soil infiltration rates. The range of concentrations in soil and surface runoff for vineyards and villages was wider than that of other types of land because of the intensification of human activities.

In China, farmers traditionally live close to water resources, such as rivers, lakes and reservoirs. A small number of livestock is often fed by an individual farmer in one area. Animal waste is often piled up and stored openly without effective management. Most villages lack waste collection systems and wastewater treatment facilities. In the two catchments, livestock excretion often piles up beside village roads, and this 
Table 3 Comparison of some characteristics for various landscapes of the two study catchments

\begin{tabular}{|c|c|c|c|c|c|c|c|c|}
\hline \multirow[t]{2}{*}{ Land use } & \multirow[t]{2}{*}{ Land cover } & \multirow[t]{2}{*}{$K d\left(\mathrm{~mm} \mathrm{~h}^{-1}\right)$} & \multicolumn{3}{|l|}{$\begin{array}{l}\text { Nutrient contents } \\
\text { in soil }\left(\mathrm{g} \mathrm{kg}^{-1}\right)\end{array}$} & \multicolumn{3}{|c|}{$\begin{array}{l}\text { Nutrient concentrations } \\
\text { in surface runoff }\left(\mathrm{mg} \mathrm{l}^{-1}\right)\end{array}$} \\
\hline & & & $\mathrm{TN}$ & $\mathrm{TP}$ & $N$ & $\mathrm{TN}$ & $\mathrm{TP}$ & $N$ \\
\hline Hill land & Pine and grass & 56.4 & $0.39(0.35-0.72)$ & $0.19(0.12-0.32)$ & 10 & $9.52(5.55-14.81)$ & $1.89(1.83-7.23)$ & 21 \\
\hline $\begin{array}{l}\text { Cropland; } \\
\text { Orchard }\end{array}$ & $\begin{array}{l}\text { Wheat and maize; } \\
\text { Hawthorn, } \\
\text { apricot }\end{array}$ & 79.8 & $0.59(0.42-1.39)$ & $0.35(0.18-1.03)$ & 88 & $14.27(3.85-24.71)$ & $2.39(0.45-8.16)$ & 74 \\
\hline Vineyard & Grape tree & 67.2 & $0.91(0.57-1.48)$ & $0.80(0.48-1.48)$ & 24 & $25.64(15.21-55.41)$ & $8.71(1.18-74.53)$ & 57 \\
\hline Village & $\begin{array}{l}\text { House, unpaved } \\
\text { road, garden }\end{array}$ & 4.2 & $0.82(0.39-3.90)$ & $0.60(0.28-2.06)$ & 18 & $17.53(5.48-91.75)$ & $4.64(1.64-34.63)$ & 89 \\
\hline Woodland & Alamo, tussock & ND & $0.52(0.41-0.58)$ & $0.21(0.17-0.33)$ & 9 & ND & ND & ND \\
\hline
\end{tabular}

Data of nutrient contents in soil and surface runoff are shown as median (maximum-minimum)

$T N$ total nitrogen; $T P$ total phosphorus; $K d$ soil saturated hydraulic conductivity; $N$ the number of samples; $N D$ not determined

adds to surface runoff nutrients. Grapes are a cash crop in $\mathrm{T}$ catchment; they require a large amount of fertilizer and manure. The high nutrient input leads to high nutrient export risk, especially when manure is applied before rainstorms. TN and TP concentrations in surface runoff peaked to 55.41 and $74.53 \mathrm{mg} \mathrm{l}^{-1}$, on July 26,2004 , only three days after the fresh surface application of liquid poultry manure.

Landscape spatial patterns and nutrient transport processes

The landscape spatial patterns in the two catchments are mapped in Fig. 1. The landscape spatial pattern in $\mathrm{T}$ catchment was hill land-village, vineyard, orchardcropland-woodland-eulittoral zone from upstream to the receiving waters. The village and vineyard areas are about $1,500 \mathrm{~m}$ away from the outlet. The spatial pattern in $\mathrm{C}$ catchment was hill land-cropland, orchard-village-eulittoral zone. The distance of a village from the outlet was about $200 \mathrm{~m}$,-nutrients could discharge into receiving water directly in $\mathrm{C}$ catchment.

$\mathrm{TN}$ and TP concentrations in the transport pathway are shown in Fig. 4. The nutrient concentration in surface runoff varied with hydrological pathways and landscapes. Nutrient concentrations across the village were the highest among all landscapes, followed by cropland and orchard. Hill land and eulittoral zone shared the lowest nutrient concentrations. In the two typical rainfall-runoff events, nutrient concentrations at the outlets of $\mathrm{T}$ catchment were higher than those of C catchment.

Micro-topography within the two catchments

The micro-topography in the research area has changed greatly after a long history of intensive cultivation. Many natural and man-made micro-topographical structures are distributed among the two catchments, such as gullies, depressions, terraces, field mounds, ponds, and field tracks, lanes, dams and vegetated filter strips. This creates a complex earth surface system and increases surface roughness (Fig. 1, Table 1). Most of the cultivated landscape in the two catchments has been developed into terraces, with a gentle slope of less than $5^{\circ}$. These terraces are often divided into many small blocks of 0.1-0.5 ha. This pattern increases the density of the border per unit area. Small earth mounds or ridges were usually constructed to separate and denote the different owners or harvest rainfall. The height of earth mounds around fields usually ranges within $5-15 \mathrm{~cm}$. If a flat field is well closed with earth mounds to a height of $10 \mathrm{~cm}$, it should have the capacity of storing $10 \mathrm{~cm}$ depth of runoff (Fig. 5).

In the north part of hilly areas of $\mathrm{T}$ catchment, deep gullies, depressions and man-made dams could be shaped into small reservoirs to store surface runoff, and enhanced infiltration. No surface water could discharge from those areas without significant rainfall. Many small ponds for fish, irrigation or collecting earth for construction are also scattered within $\mathrm{T}$ catchment. Ponds within $\mathrm{T}$ catchment are estimated to store about $8,600 \mathrm{~m}^{3}$ water, or $4.5 \mathrm{~mm}$ depth surface runoff. Several small stone dams have also been built to intercept sediments. Wang et al. $(2004,2005)$ noted that a series of artificial and natural buffer/detention landscape structures in the hydrological pathway, such as four small stone dams, a roadside grassed ditch, a vegetated filter strip, two dry ponds and a eulittoral zone, could effectively reduce the export load of sediment and nitrogen in surface runoff. The flow velocity and runoff volume were the two key factors determining nutrient load export. Nutrients were transferred without any detention in filed tracks and lanes in $\mathrm{C}$ catchment. These tracks were often compacted by footstep and agricultural machinery. 
Fig. 4 Spatial variations of $\mathrm{TN}$ and TP concentrations within hydrological pathways of the two catchments. a T catchment on June 22, 2003, cited from Wang et al. (2004, 2005); b C catchment on August 25, 2004. Black squares stand for TN, empty circles stand for TP. Vertical bars stand for standard deviation. Landscapes around the sampling sites are also given

Fig. 5 Small earth ridges and mounds within the two study catchments
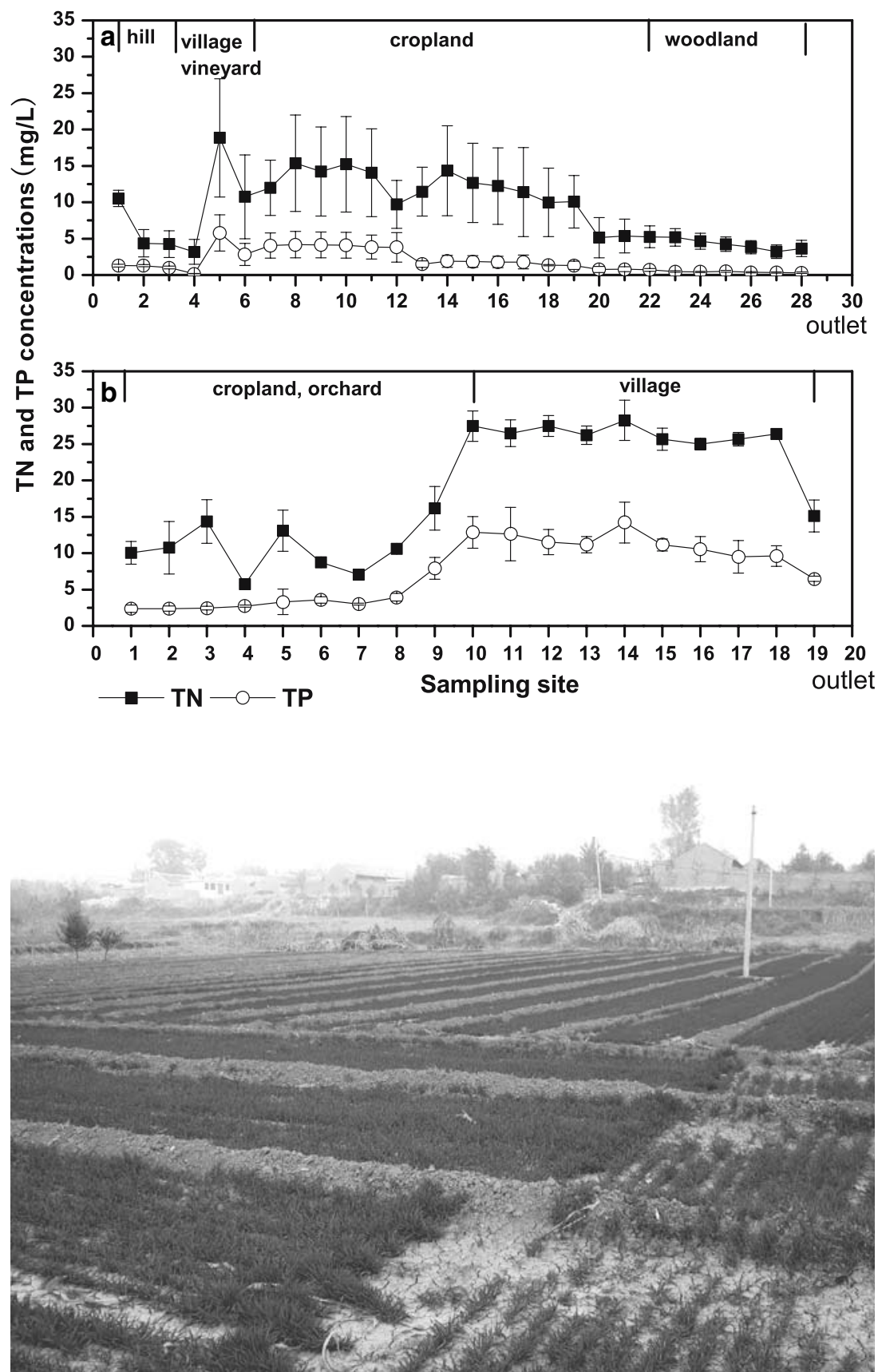

\section{Discussion}

Effects of landscape spatial patterns

In the two catchments, village and vineyard had the heaviest nutrient pollution. Woodland can remove nutrients through uptake, settlement, sorption, denitrification et al. (Hill 1996; Casey and Klaine 2001). The eulittoral or wetland zone, mainly covered by sparse grass was able to detain nutrients during lower surface water levels in the reservoir, but could play no role in nutrient attenuation when submerged. During most of the study period, the eulittoral zone was submerged. When this eulittoral zone was not above water, there was no buffer zone for nutrient export moving toward the receiving water of the Reservoir. The landscape spatial pattern determined the distribution of nutrient source. The longer distance a nutrient traveled, the higher the possibility of nutrient detention. In $\mathrm{T}$ catchment, nutrient pollution from village and vineyard were reduced during transport because of the long travel distance of about 1,500 m. In 
C catchment, the short distance of about $200 \mathrm{~m}$ between village and the outlet almost resulted in no nutrient reduction.

Landscape spatial patterns not only determine nutrient spatial distributions, but also affect spatial transport processes. In the transport pathways of the current study of $\mathrm{T}$ and $\mathrm{C}$ catchments, surface runoff nutrient concentrations near the village and vineyard always shared the highest concentrations (Fig. 4).

\section{Effect of micro-topography}

At finer scales, micro-topography can concentrate or disperse runoff. It can reduce overland flow velocity, and surface water ponds in small depressions (Bergkamp 1998; Kirkby et al. 2002; Cammeraat 2004; Imeson and Prinsen 2004). Micro-topographical features can be differentiated as source and sink features. Source features refer to runoff generation areas with nutrient export, which often have high nutrient mobility potential. Bare land, unpaved roads and compacted cultivated land usually were source features. Sink features were primarily those areas where water and nutrients could be absorbed. Dams, ponds, field mounds and terraced lands were sink features. Ponds could store water from surrounding areas and effectively reduce agricultural pollutant loads to streams and lakes (Yin et al. 1993; Fiener et al. 2005). Water behind the earth mounds and dams could increase infiltration (Bergkamp 1998). Huang and Zhang (2004) found conservation practices had a great impact on the flow regime when they investigated the hydrological response to soil conservation practices in a moderate-size catchment in the Loess Plateau of China. The types of soil conservation practices implemented in the catchment mainly included planting of trees, establishing manmade grassland, construction of terraces and small gully erosion control dams. The latter two features were common in this current study.

In the two study catchments, ponds, earth mounds and terraces were common sink features, which provided water storage capacity and enhanced infiltration, thus increasing the runoff generation threshold. The number and buffering capacity of sink features in $\mathrm{T}$ catchment were greater than in $\mathrm{C}$ catchment. This may explain why the rainfall threshold for runoff generation (about $20 \mathrm{~mm}$ ) in $\mathrm{T}$ catchment was higher than that in C catchment (about $10 \mathrm{~mm}$ ).

Hydrological connectivity is another important factor controlling whether water and nutrients can be transferred into the ultimate water bodies (McDowell et al. 2001; Heathwaite et al. 2003; Heathwaite et al. 2005). Along a transport pathway, longer pathways increase local storage possibilities. In the present study area, sink features such as stone dams, vegetated filter strips, and dry ponds effectively detained runoff and nutrients within the ephemeral stream in T catchment (Wang et al. 2004, 2005). When there is low rainfall amount, then sink features could discontinue water flow. Hydrological pathways made up of earth can absorb water through storage in soil and infiltration. However, during high rainfall events, nutrients that have accumulated in transport pathways during the previous rainfall-runoff events can also be resuspended and transferred with water flow.

Recently, some of the ephemeral streambeds have been cultivated as cropland or orchards. Such activities have two controversial ecological results. On the one hand, maize or trees can increase surface roughness and discontinue surface runoff. On the other hand, fertilizer application in ephemeral streams increases the nutrient export risk. In small rainfall-runoff events, the former phenomenon often dominates, while the latter may play the main role in large storm events. Such a discrepancy can also partly explain why nutrient load transferred in these large storm events occupies such a very high proportion of the total. In the long run, agricultural activities in hydrological pathways in $\mathrm{T}$ catchment may need to be banned. Otherwise, sink features and hydrological pathways could become nutrient sources during large storm events. In $\mathrm{C}$ catchment, there were no sink features along the transport pathway but the transport pathway itself was also a nutrient source. Surface runoff on unpaved roads, lanes and field tracks was more likely to become concentrated. Then, nutrients accumulated on the top of the soil were more easily transferred. Special efforts are required to familiarise local farmers with environmentally friendly agricultural production techniques and prevent nutrient pollution away from hydrological pathway. These efforts need to include explanations of the urgency of taking special measures in order to preserve the Reservoir drinking water. Economic supports for farmers will be needed to assist farmers in building ponds and in finding ways to sequester manure piles so they are not subject to rainstorm.

\section{Conclusion}

The nutrient export from agricultural catchment can be affected by not only the nutrient source but also the landscape spatial pattern and micro-topography. The distance between the pollution source area and the catchment outlet, and the sink structures in the runoff 
pathways were key factors in determining the nutrient export rate in the catchments have been studied.

In T catchment, there was $1,500 \mathrm{~m}$ between the main pollution source area and the receiving water, and there were sink structures of small stone dams, roadside swale, vegetated strip and dry ponds, which could retain water, sediment and nutrients. In $\mathrm{C}$ catchment, the shorter distance of about $200 \mathrm{~m}$ between the village and reservoir, and few sink structures resulted in direct nutrient discharge into the reservoir. These differences made the TN and TP export rates from $\mathrm{C}$ catchment 6.6 and 20.6 times as much as those from $\mathrm{T}$ catchment.

To reduce nutrient export and control eutrophication in the reservoir, not only should the nutrient source be controlled, but also the hydrological pathway. Ecological engineering measures could be used to optimize the landscape spatial configuration and better control nutrient transfer from the agricultural catchments.

Acknowledgments The authors gratefully acknowledge the financial support by the National Basic Research Priorities Program (2006CB403306) and the National Hi-Tech Research Program (2002AA601011-05). We are also grateful to the local farmers for their field assistance, to Desiree Tullos, Janice Willson, Alice Honig and two anonymous reviewers for their helpful comments and language corrections of the manuscript.

\section{References}

Bergkamp G (1998) A hierarchical view of the interactions of runoff and infiltration with vegetation and microtopography in semiarid shrublands. Catena 33:201-220

Beven KJ, Kirkby MJ (1979) A physically based variable contributing area model of basin hydrology. Hydrol Sci Bull 24:43-69

Boyer EW, Goodale CL, Jaworski NA, Howarth RW (2002) Anthropogenic nitrogen sources and relationships to riverine nitrogen export in the northeastern USA. Biogeochemistry $57,58: 137-169$

Cammeraat ELH (2004) Scale dependent thresholds in hydrological and erosion response of a semi-arid catchment in southeast Spain. Agric Ecosyst Environ 104:317-332

Cao ZH (2003) Effect of fertilization on water quality-effect of fertilization of on environment quality (2). Soils 35(5):353363 (in Chinese)

Cao WZ, Hong HS, Zhang YZ, Chen NW, Zeng Y, Wang WP (2006) Anthropogenic nitrogen sources and exports in a village-scale catchment in southeast China. Environ Geochem Hlth 28(1-2):45-51

Casey RE, Klaine SJ (2001) Nutrient attenuation by a riparian wetland during natural and artificial runoff events. J Environ Qual 30:1720-1731

Chen LD, Fu BJ, Zhang SR, Qiu J, Guo XD, Yang FL (2002) A comparative study on nitrogen-concentration dynamics in surface water in a heterogeneous landscape. Environ Geol 42:424-432

Chen LD, Peng HJ, Fu BJ, Qiu J, Zhang SR (2005) Seasonal variation of nitrogen-concentration in the surface water and its relationship with land use in a catchment of northern China. J Environ Sci 17(2):224-231

Chen NW, Zhang LP, Hong HS, Liu JC (2004) Estimation of household wastewater loads from Jiulong river watershed. J Xiamen Univ (Nat Sci) 43(Suppl):249-253 (in Chinese)

Ebina J, Tsutsui T, Shirai T (1983) Simultaneous determination of total nitrogen and total phosphorus in water using peroxodisulfate oxidation. Water Res 17:1721-1726

Fiener P, Auerswald K, Weigand S (2005) Managing erosion and water quality in agricultural watersheds by small detention ponds. Agric Ecosyst Environ 110:132-142

Haygarth PM, Condron LM, Heathwaite AL, Turnerd BL, Harris GP (2005) The phosphorus transfer continuum: linking source to impact with an interdisciplinary and multi-scaled approach. Sci Total Environ 344:5-14

Heathwaite AL, Fraser AI, Johnes PJ, Hutchins M, Lord E, Butterfield D (2003) The phosphorus indicators tool a simple model of diffuse $\mathrm{P}$ loss from agricultural land to water. Soil Use Manage 19:1-11

Heathwaite AL, Quinn PF, Hewett CJM (2005) Modelling and managing critical source areas of diffuse pollution from agricultural land using flow connectivity simulation. J Hydrol 304:446-461

Herpe YV, Troch PA (2000) Spatial and temporal variations in surface water nitrate concentrations in a mixed land use catchment under humid temperate climatic conditions. Hydrol Process 14:2439-2455

Hill AR (1996) Nitrate removal in stream riparian zones. J Environ Qual 25:743-755

Huang MB , Zhang L (2004) Hydrological responses to conservation practices in a catchment of the Loess Plateau China. Hydrol Process 18:1885-1898

Imeson AC, Prinsen HAM (2004) Vegetation patterns as biological indicators for identifying runoff and sediment source and sink areas for semi-arid landscapes in Spain. Agric Ecosyst Environ 104:333-342

Kirkby M, Bracken L, Reaney S (2002) The influence of land use soils and topography on the delivery of hillslope runoff to channels in SE Spain. Earth Surf Proc Land 27:1459-1473

Lane SN, Brookes CJ, Kirkby MJ, Holden J (2004) A networkindex-based version of TOPMODEL for use with highresolution digital topographic data. Hydrol Process 18:191-201

Li Y, Zhang JB (1999) Agricultural diffuse pollution from fertilisers and pesticides in China. Water Sci Technol $39(3): 25-32$

Liu CM, Xia J (2004) Water problems and hydrological research in the Yellow River and the Huai and Hai River basins of China. Hydrol Process 18:2197-2210

Mander U, Kull A, Kuusemets V, Tamm T (2000) Nutrient runoff dynamics in a rural catchment: influence of land-use changes climatic fluctuations and ecotechnological measures. Ecol Eng 14:405-417

McDowell RW, Biggs BJF, Sharpley AN, Nguyen L (2004) Connecting phosphorus loss from agricultural landscape to surface water. Chem Biol 20(1):1-40

McDowell R, Sharpley A, Folmar G (2001) Phosphorus export from an agricultural watershed: linking source and transport mechanisms. J Environ Qual 30:1587-1595

Ngoye E, Machiwa JF (2004) The influence of land-use patterns in the Ruvu river watershed on water quality in the river system. Phys Chem Earth 29:1161-1166

Smith VH, Tilman GD, Nekol JC (1999) Eutrophication: impacts of excess nutrient inputs on freshwater marine and terrestrial ecosystems. Environ Pollut 100:179-196

Walter MT, Walter MF, Brooks ES, Steenhuis TS, Boll J, Weiler K (2000) Hydrologically sensitive areas: variable source area 
hydrology implications for water quality risk assessment. J Soil Water Conserv 3:277-284

Wang XH, Yin CQ, Shan BQ (2004) Control of diffuse Ppollutants by multiple buffer/detention landscape structures by Yuqiao Reservoir, North China. J Environ Sci 16(4):602606

Wang XH, Yin CQ, Shan BQ (2005) The role of diversified landscape buffer structures for water quality improvement in an agricultural watershed North China. Agric Ecosyst Environ 107:381-396

Weld JL, Sharpley AN, Beegle DB, Gburek WJ (2000) Identifying critical sources of phosphorus export from agricultural watersheds. Nutr Cycl Agroecosys 59:29-38

Withers PJA, Lord EI (2002) Agricultural nutrient inputs to rivers and groundwaters in the UK policy environmental management and research needs. Sci Total Environ 282,283:9-24

Wetzel RG (ed) (2001) Limnology: lake and river ecosystem, 3rd edn. Academic, San Diego, CA, pp 1006

Xia LZ, Yang LZ, Wu CJ, Wu YF (2003) Distribution of nitrogen and phosphorus loads in runoff in a representative town in Tailake Region. J Agron-Environ Sci 22(3):267-227 (in Chinese)

Yin CQ, Zhao M, Jin WG, Lan ZW (1993) A multi-pond system as a protective zone for the management of lakes in China. Hydrobiologia 251:321-329

Zhu X (1991) Control of eutrophication of yuqiao reservoir. Science and Technology Press of Tianjin, Tianjin, China (in Chinese) 